\title{
Beyond the Middle East: Saudi-Iranian Rivalry in the Horn of Africa
}

\author{
Alieu Manjang \\ Qatar University, Doha, Qatar
}

\begin{abstract}
The rivalry between Iran and Saudi Arabia is one of the familiar features of the Middle East regional politics. However, this rivalry seems to have split-over beyond the Middle East region. In the Horn of Africa ${ }^{1}$, Riyadh and Tehran are engaging in a fierce competition for position and influence. Against this background, this paper explains how Saudi-Iranian rivalry initiated in the Horn of Africa. More precisely, the paper takes the advantages of sub-theory of Neo-Realism, i.e. Defensive Realism 's notion of alliance building to explain how Iran's endeavor to become stronger vis-à-vis Saudi Arabia initiated their rivalry in the Horn of Africa prior to the Arab Spring. Likewise, the paper borrows from Constructivism's notion of perception of threat to explicate Saudi's perception of Iranian threat in the Horn of Africa, which shaped and continued to dynamite Saudi-Iranian rivalry in the region. To this end, the paper would rely on secondary resources to prove that Saudi Iranian rivalry in the Horn of Africa was encouraged by Saudi's de-engagement in the region since the outset of 1990s and parallel Iran's penetration into region in the same period. The subsequent Saudi diplomatic effort to de-ignite the perceived Iranian growing influence in the Horn inflamed their rivalry in the region, which has reached its summit during the Arab Spring.
\end{abstract}

Keywords: Iran, Saudi Arabia, rivalry, Horn of Africa

\section{Introduction}

The history of the nation-state has been fraught with competition and conflict. In the fight for sovereignty and political legitimacy, nations have been willing to compete over beliefs, resources and influence. Thus, rivalry became a constant feature of international relations. This is evidenced by larger number of interstate rivalry that characterized the relationship between dyadic states across the world (Mitchell \& Thies, 2011). In the Middle East region, the Saudi-Iranian rivalry continues to define, shape and reshape the strategic imbalance and direction of the Middle East's regional politics since the Iranian Revolution in 1979. Their rivalry, which commenced in late 1970 but compounded by the fall of Saddam Hussein following the 2003 U.S invasion and the subsequent establishment of a Shi'ite Iraq and the 2011 Arab Uprisings, has been responsible for major political shift that occurred in the Middle East region since the fall of Saddam's regime in Iraq in 2003 (Wehrey, Karasik, Nader, Ghez, \& Hansell, 2009). The dynamics of diplomatic and economic arrangements in the Arabian Gulf, the political turmoil in Lebanon, enduring conflict in Palestine, and mounting tactical anxieties around the world about Iran's alleged pursuit of nuclear weapons have all, to a larger extent, been shaped by the competing interests between Saudi Arabia and Iran (Wehrey et al., 2009). More recently, the competition

\footnotetext{
Alieu Manjang, Ph.D. candidate, College of Arts and Science, Qatar University.

${ }^{1}$ In this paper, the term of the Horn of Africa denotes to a region that contains countries of Djibouti, Eritrea, Sudan, Ethiopia, and Somalia.
} 
between Iran and Saudi Arabia for regional influence stands behind number of existing disputes in the Middle East region, where the two powers are backing different sides (Salisbury, 2015). For example, while local factors are responsible for the tensions and conflict in Yemen; however, the perceived and often exaggerated roles of exterior players like Saudi Arabia and Iran, who are believed to be supporting different sides, continue to affect the calculations of the Yemeni players and of different regional actors (Matthiesen, 2015).

Although realpolitik is salient in compounding the Iran-Saudi Rivalry, the politics of identity i.e. the old differences of Sunni versus Shiite and Arab versus Persian is a factor that have overshadowed more salient dimension of Saudi-Iranian rivalry. This is more evident in Saudi and Iranian approaches to the Arab uprisings as they competitively engaged in supporting friendly Sunni or Shiite regimes that face protest movements, while they find themselves in the tight position of blowing opposition when it threatens their adversaries (Wehrey, 2011). During the Arab Spring, Iran stood on the side of political change as a pathway to Shiite empowerment in Bahrain while in Syria Tehran opposes firmly the regime change. In both cases the revers approach is taking by Saudi Arabia.

Whereas the manipulation of the sectarian card, which has underpinned Saudi and Iran's responses to the Arab Spring in the region, is not an unfamiliar feature of the Middle East regional politics, the intensity of Saudi-Iranian regional rivalry amid the Arab Spring has been felt elsewhere beyond the Middle East region. In the Horn of Africa, Riyadh and Tehran are engaging in a fierce competition for position and influence. This antagonism reached the pinnacle when number of countries in the Horn of Africa tracked Saudi's pathway by severing their diplomatic ties with Iran following Iranians' attack on Saudi embassy and consulate in Iran, which was sparked by the execution of a Saudi Shia cleric Namir Al Namir in early January 2016 (Fakude, 2016a).

In the backdrop of the growing rivalry between Saudi Arabia and Iran in the Horn of Africa, this paper explains how Saudi-Iranian rivalry initiated in the Horn of Africa. More precisely, the paper takes the advantages of sub-theory of Neo-Realism, i.e. Defensive Realism's notion of alliance building to explain how Iran's endeavor to become stronger vis-à-vis Saudi Arabia initiated their rivalry in the Horn of Africa prior to the Arab Spring. Likewise, the paper borrows from Constructivism's notion of perception of threat to explicate Saudi's perception of Iranian threat in the Horn of Africa, which shaped and continued to dynamite Saudi-Iranian rivalry in the region amid the Arab Spring.

To this end, the paper would rely on secondary resources to prove that Saudi Iranian rivalry in the Horn of Africa was encouraged by Saudi's de-engagement in the region since the outset of 1990s and parallel Iran's penetration into the region in the same period. The subsequent Saudi diplomatic effort to de-ignite the perceived Iran growing influence in the Horn inflamed their rivalry in the region, which has reached its summit during the Arab Spring. The Isolation of Iran by the U.S and its regional allies in the Gulf reinvigorated Tehran diplomacy, amid the threat of international sanctions to build a strong economic, political and military relations with the countries of the Horn Africa. Iran achieved this momentum in the Horn amidst Saudi's preoccupation with balancing the Iranian threat in Gulf region as Riyadh got closer to the US and the West, while it relies on checkbook diplomacy in its engagement with countries of the Horn of Africa. Therefore, the recent escalation of Iranian-Saudi rivalry in the Horn reflects Saudi's paranoid with perceived Iran's growing influence in the Horn which is not only strategic for regional struggle for influence between Saudi Arabia and Iran, but it is also intrinsically important for economic, political and security interests of both countries.

To explain this argument further, the paper will be constructed into three parts. In first part, the attention 
will be given to the discussion of theoretical frameworks that will be employed to analyze the issue at hand. In the subsequent part, the paper will be devoted to the discussion of Saudi's retreat and Iran's entry into the Horn of Africa. In the final part of the paper, the focus will be on the evolving Saudi foreign policy towards the Horn of Africa as form of confrontation with Iran amid their proxy war in Yemen. The paper will be concluded by forecasting the nature of Iran-Saudi engagement in the Horn of Africa in light of prevailing regional politics. Until recently, the Saudi-Iranian rivalry beyond the Middle East garners less academic attention; thus, this paper contributes in the existing literature on the Saudi-Iranian rivalry by filling this neglected part.

\section{Rivalry: Theoretical Perspectives}

International Relations theories develop divergent positions in relations to what initiates or terminates interstate rivalry. This divergence mirrors their disagreements over the nature of state as agent and actor, and their understanding of international system. The following theoretical framework examines these theoretical issues. I first present a rigorous and general discussion on Realism; afterward, I present Defensive Realists' approach to how rivalry is initiated in international system. Secondly, I present general discussion about Constructivism, and the conditions under which ideational forces dominate threat perception which finally lead to rivalry between two states.

\section{Initiation of Rivalry from Defensive Realist Perspective}

The explanation of how states initiate their rivalry relations is rooted in the realist theory of international relations, which also serves as theoretical root from which Neo-Realism was developed. Largely, Realism views the relations between states as struggle for material power among self-interested players, i.e. states (Donnelly, 2000). In its traditional garment, realists believe that states, which are ruled by sovereign governments with absolute and credible power, are akin to human beings in that they have innate desire to dominate others, which consequently leads them to fight wars (Donnelly, 2000; Morgenthau, 1965; Rohde \& Morgenthau, n.d.). Thus, Realists are generally pessimistic about the prospects for cooperation and elimination of conflict and war between states because international condition is anarchic. The anarchic nature of the international system - which is created by the absence of central authority - makes states, as believed by realists, to be in perpetual threat of war and conflict because of fear caused by lack of trust and competition among themselves. This nature, in turn, prompts states to relentlessly seek power and security because they exist in a self-help system (Moravcsik, 1997).

However, Realism is not a homogenous theory; the theory has evolved considerably throughout the Cold War. Neo-Realism theory, which was developed by Kenneh Waltz (1988), overlooked the human nature of the states and focused on the balance of power in international system. For Waltz, the international system comprises of a number of great powers, each strive to survive. As the system is disordered or anarchic (there is not central authority that protects states from one another) each individual state has to depend on itself to survive. According to Waltz, this condition prompts weaker states to balance against, rather than competing with powerful states (Walt, 1998).

Form the proceeding paragraphs we can see that rivalry and competition for power and survival is central in Realism theory in general. However, the centrality of rivalry in Realism has been further elaborated by neo-realists, albeit different from classical Realism. As neo-realists focus on the system rather the on model-human being state, they believe that rivalry between states starts with the alteration in the configuration 
of the system, and it ends when that system changed again (Dreyer, 2012). This is endorsed by sub-schools of Neo-Realism, i.e. defensive and offensive Realism. Accordingly, Defensive Realism posits that states' attempt to prevent or deter territorial occupation or military and political domination of the state by a power state or coalition force state to forge alliance in an anarchic international system (Baldwin, 1993; Hellmann \& Wolf, 1993; Keohane, 1986). In the case that the system is a multipolar system, balancing would manifest in joining a particular bloc with the aim of deterring another bloc or individual. As such, the tendency to form an alliance to deter the threat of others exhibit to change the system; the effect of this within the system manifests in competition for beefing up military and economic capabilities in order to remain strong vis-à-vis others. This competition could result in rivalry over wining new allies; assertive foreign policies for fortifying and enhancing influence over territories (Dreyer, 2014).

The US emergence as super power on the wake of World War Two did not only alter the international system, but it also led to the ignition of rivalry between the U.S and Soviet Union or between the Western bloc led by the U.S, and the Eastern bloc led by the Soviet Union. Their rivalry overridden the U.S-Soviet Union relations in different parts of the world, and virtually over all issues (Crockatt, Sayigh, \& Bromley, 1997). Similarly, in the Middle East region, the balance of power has altered significantly in the favor of Saudi as the result of its military and economic alliance with the US. This development has undermined Iran's regional ambitions; and forced Tehran to seek alliance beyond the Middle East region, which entailed confronting Saudi Arabia in its sphere of influences including in the Horn of Africa (Aarts \& Pwhaartsuvanl, n.d.). While Iran maintained strong relations with countries of the Horn of Africa in last two decades, the escalation of conflicts in the Middle East amid the Arab Spring, in which Iran and Saudi Arabia stand on opposite side, pushed Saudi Arabia to confront Iran in the Horn of Africa in correspond to threat perception of Iran in the region.

\section{Threat Perception and Interstate Rivalry}

The threat perception, which informs policy responses of states, rest upon the foundation of Constructivism theory of international relations, and it is central in constructivist explanation of how rivalry is initiated between states. In its totality, Constructivism is with the view that states develop their relations with, and understandings of, others through the media of norms and practices (Adler, 2008; Hopf, 1998). Constructivists' strong belief in mind and concept leads them to critique realists in their obsession with anarchy. For them, anarchy is an imagined community and it is mutually constituted by actors employing constitutive rules and social practices. Thus, they believe that anarchy has multiple meanings for different actors based on their own communities of inter-subjective understandings and practices (Wendt, 2014; Wendt, 1992). In respect to identity, they hold that identities are necessary, in international politics and domestic society alike, in order to ensure at least some minimal level of predictability because the identity of a state implies its preferences and consequent actions. Unlike Realism who reduces power to material power, Constructivism argues that both material and discursive power are necessary for any understanding of world affairs (discursive power of knowledge, ideas, culture, ideology, and language) (Wendt, 2014; Wendt, 1992).

As Constructivism posits that international relations is contingent and dictated by social facts that help us to understand the reality, and past experience, which also shape our current reality, this social fact and past experience are also central in defining what constitutes a threats to a state (Wendt, 1992). The constructivists treat of threats are not objective and materially-based facts; rather, threats are socially constructed. In the construction of what is perceived as a threat, crucial are identities and ideas; hence, identity provides a better 
conceptual lens for threat perception than material factors from the perspectives of constructivists. Thus, according to constructivists, material forces are dependent on ideational factors in perceiving what constitute as threat and in determining the action of states to that threats (Guzansky, 2015).

What should be understood from the ongoing argument of constructivist is that threat perception is a function of what can we call as ideological distance. The ideological distance between two states i.e. the degree of ideological differences, emboldens the perception of threat which serve as source of conflict among states. The ideological schism between Saudi Arabia and Iran accounts for the Saudi perception of Iran as an ideational threat (Rizwan, Iram, \& Waqar, 2014). This has played out in the Middle East politics and it has been responsible for their rivalry in the region and beyond. Likewise, Iran's entry into Horn of Africa, in which it built strong ties with different countries, is perceived by Saudi Arabia as threats to the Kingdom. The perception of Riyadh that Tehran would use the region to extent its support to allies in the Middle East encouraged the Kingdom of Saudi Arabia to confront Iran in the Horn of Africa in light of Yemen civil war. In the following section we examine Iran's entry into the Horn of African and the subsequent rivalry between Tehran and Riyadh.

\section{Saudi's Retreat and Iran's Ascendancy in the Horn of Africa}

What follows we combine constructivists notion of threat perception and Defensive Realism's notion of balance of power to explain on the one hand, Saudi' engagement in and retreatment from the Horn of Africa from 1960s to early 1990s; and expansion of Iran's foreign relations with countries of the Horn of Africa.

\section{Saudi's Retreat from the Horn of Africa}

Historically, and in comparison with Iran, Saudi has a long history of political and cultural activities in the Horn of African. While the political and strategic importance of this part of the world and its geographical proximity to Saudi Arabia could be seen as essential in Saudi's interest in the region, it was primary threat perception of the Soviet Union and Israeli that explained Saudi Arabia longstanding presence in the region from 1960s to the end of 1970. From 1960s to 1970s, Saudi Arabia was primary concerned over the Soviet Union's behaviors in expanding communist influence in the region (Long, 1990). Saudi Arabia didn't not only perceive the communist activities in the Horn of Africa as a threat to way of life of the Muslim communities under Marxist regimes like Ethiopia, but Saudi felt threatened by the rising influence of the Soviet in countries which are either members of the Arab league, like Sudan and Somalia, or border on or are across the Red Sea which crucial for the trade link with world. In this context, Saudi bent on traditional and public diplomacy as foreign policy instruments to stem Soviet political inroad in the region. For example, Saudi Arabia and the United States tried in vain to persuade Somali President Siad Barre not to allow the Soviets to have their base at Berbera (Long, 1990). Despite this, Saudi offered diplomatic and financial support to Somalia during their war with Ethiopia in 1970s and 1980s. Although Somalia was under orbit of Soviet Union, Saudi didn't hesitate to offer its support to Somalia as it was fighting not only another communist regime, but also a close ally of Israel. Likewise, Saudi Arabia backed Eritrea Muslim freedom fighters in their war with Ethiopia, who was under the support the Soviet Union (Long, 1990).

While the existence of Soviet was the primary concern for Saudi Arabia, the Arab-Israel war constituted another factor that pushed Saudi Arabia to maintain its influence in the Horn of Africa. Towards this end, Saudi used its oil boom leverage to support regimes in the region especially Sudan and Somalia win their support in 
exchange for financial assistance (Akinsanya, 2010; Yoh, 2001; Obala, 2011). The primary goal of Saudi public diplomacy was to increase its soft power in the countries of the Horn of Africa through the diffusion of Wahhabism. This was deemed necessary to win the hearts and the minds of the people for the Saudi's course, while official development assistance was used to distance these countries from Israel. Ultimately Saudi Arabia the most employed way to do so, has been that of donations to schools, mosques, research centers and religious organizations. In Somalia for Example, Saudi Arabia petrol dollar sponsored the establishment of Islamist organizations like al-Nahdah (1967), al-Wahdah (1969) and Al-Ahli, the latter founded in Mogadishu in 1970 (Zoppi, 2013).

However, political developments in the Middle East, personalized in the Camp David Accord, the Islamic Revolution of Iran, the Iraq-Iran war and Iraqi invasion of Kuwait in 1991, discouraged Saudi political activities in the Horn of Africa as Riyadh's concerns remained fixed on regime survival amid expansionist behaviors of Iran and Iraqi in the region. Although Saudi sponsored-institutions remained active in protecting and representing Saudi interest in the region, the terrorist attacks on the U.S embassies in Kenyan Capital Nairobi and Tanzanian Capital Darussalam in 1998 not only pacified Saudi activities in the region but also marked its retreatment from the region, especially after 9/11 attacks as international pressures on Saudi Arabia forced her to close score of charitable organizations that were linked to recruiting and supporting terrorists around the world (Zoppi, 2013).

Despite this, the Saudi's efforts to balance against the threat of Iran in the Middle East region since the establishment of theological regime in Iran in 1979 served as another factor that enforced Saudi treatment from the Horn of Africa, as Riyadh devoted its diplomacy and resources to stand up for regional threats of Iran. Since its outset in 1979, the establishment of Iran's theocratic regime in the vicinity of Arab territories went hand in hand with parallel Iran's effort to infiltrate Arab borders with introduction of revolutionary ideologies to its people. This have aroused the anger and the apprehension of Arab Gulf regimes, who were seeking for strong military replacement in the region following the withdrawal of the British from the region in 1971 (Cronin \& Masalha, 2011). The apprehensions of Riyadh and other Gulf states regarding the Iranian threats was vindicated by the rebellion of the Shia people in Saudi Arabia's oil-rich Eastern Province, and the 1981 coup plot by the Iranian-backed Islamic Front for the Liberation of Bahrain. These concurrent incidences caused many Gulf States to consider Iran a greater threat and this subsequently led the smaller Gulf States to the formation the Gulf Cooperation Council (GCC) with Saudi Arabia in 1981 as balancing mechanism of Iranian threat in the region (Downs, 2012).

Iran's threats to its neighbor was muted to a larger extent from 1982 to late 1988 as Tehran military energy was devoted to its eight year war with Iraq; and due to the changes in leadership in Tehran, as Iran changed from an ideological foreign policy to a more realistic one from 1989 to the Millennium (Downs, 2012). Despite that Iran improved its relations with its Arab neighbors from 1989, the Iraq invasion of Kuwait in 1991 and the subsequent U.S military deployment in the region has been an opportunity for the Arab Gulf states to seek military assistance from the U.S to balance any possible threat of Tehran in the Middle East. In this context, Saudi Arabia, who is the Iran contender in the region, hosted US military base in Riyadh (Yaphe, 2008). The U.S continuing interests in stopping war from threatening the political status quo in the Gulf region and from interrupting the constant flow of Saudi oil to international markets continued to guide the U.S Saudi relations, which expanded significantly in last three decades in military, economic and political arenas. The Washington's military and economic alliance with Riyadh also severed as policy of "dual containment" of both Iraq and Iran; 
thus, it has brought a change in the regional system as Iran become less powerful and threatening in the enhancement of the U.S presence in the region, while Saudi Arabia become stronger vis-à-vis Iran as the results of alliance with the U.S. Nonetheless, this has not only constituted a serving factor for Saudi's withdrawal from the Horn of Africa, but it has also permitted Iran to expand its diplomatic, political, military and economic ties with the countries of the Horn of Africa especially in the rein of Mahmoud Ahmadinejad (2005-2013).

\section{Iran's Ascendancy in the Horn of Africa}

Despite the US-Saudi military and economic alliances in the Middle East region, Iran, under the leadership of Akbar Hashmi Rafsanjani (1989-1997) and Muhammad Khatami (1997-2005), barely embarked on aggressive actions and confrontational foreign policy to alter the distribution of power in the region and to change the status quo in their favor in fear confrontation with the U.S (Hunter, 2010). However, the election of ultra-conservative president, Mahmoud Ahmadinejad in 2005 returned the values and principles of the early years of revolution to Iran's foreign relations. As a result of this, Iran's relations with the Arab Gulf state worsen as Iran condemned their allies with the "great Satan" the U.S, the blame of whose presence in the region was placed on the Saudi Arabia. Amid Iran's frustration with the presence of the U.S and its incapability to alter the system pushed Iran to substitute its isolation in region with extending its foreign relations with African countries not only to build its military and economic capabilities vis-à-vis Saudi Arabia, but also to counter international economic sanctions, which was imposed on Tehran due to nuclear program (Abdollahian, 2013).

Accordingly, the rest of Ahmadinejad's presidency witnessed extensive Iran diplomatic and political activities in Africa, and the prime focus has been promoting trade ties with African and gaining international diplomatic support for its nuclear program (Jordaan, 2008). In the Horn of Africa, Iran originally may not have had the inclination to be drawn into the Horn of Africa; however, it found it difficult to hold back due to the geo-strategic importance of the region to regional ambition. The Horn of Africa drives its geo-strategic importance from its neighboring of the Indian Ocean on the one side, and controlling of the southern entrance to the Red Sea (the Bab al-Mandeb Strait) on the other, which gives the region a dominant position vis-à-vis global trade routes, especially the shipping of crude oil originating in the Gulf and destined for Europe and the United States. These factors have not only drawn Iran to the region, but it has also attracted countries of the Arabian Gulf to the region (Lefebvre, 2012). However, as Saudi Arabia prioritized its U.S overture to that of developing countries, the Islamic Republic of Iran utilized the Saudi's absence from the Horn of Africa to successfully penetrate the region as it found its way around forging military cooperation with Sudan and building of alliance with Eritrea. The Iran alliance with Eritrea has offered the Iranian navy a friendly environment to support and extend its navy deployments in the Gulf of Aden/Red Sea. It has also provided Iran a maritime link between Iran and Syria to support its naval forces moving from the Indian Ocean through the Red Sea and Suez Canal to the Mediterranean (Lefebvre, 2012).

Iran's penetration of the region was manifested also in the diplomatic activities of Iran in number of countries in the Horn of Africa. These diplomatic activities are accompanied with the expansion of trade and investment between Iran and these countries. For example, in Ahmadinejad's visit to Djibouti in 2009, Iran signed five economic cooperation agreement and granting of credit line to Djibouti. Similarly, in his visit to Kenya Ahmadinejad was accompanied by a large delegation of private businessmen, and the visit also witnessed the signing of number of agreements which could increase the volume of bilateral trade between two 
countries to $\$ 500$ million by 2010 (Hunter, 2010, pp. 228-229). Moreover, in 2008 Eritrean President made two day visits to Iran and met with President Mahmoud Ahmadinejad and Supreme Leader Ayatollah Ali Khamenei. During this visit four agreements were signed between two countries to improve bilateral political and economic relations, including deals to expand trade and encourage Iranian investment in Eritrea's mining, agricultural, industrial and energy sectors (Lefebvre, 2012).

Thus, given the antagonistic relations and rivalry between Iran and Saudi Arabia, and the proximity of the Horn of Africa to the sphere of influences of the both countries, the Iran's outreach to the Horn of Africa has aroused the Saudi's apprehension, who maintains historical, cultural, economic and political relations with the countries of the Horn (Lefebvre, 2012). The laid the basis for the Saudi-Iranian rivalry in the region. Nonetheless, Saudi's diplomatic and foreign policy activities in the Horn of Africa remain insignificant. This is ascribed to Saudi's preoccupation with subsiding the prime Iranian threat in other sensitive and strategic locations in the region amid the Iran's ambitious and extensional foreign policy, which Tehran has unleashed since the fall of Saddam Hussain in Iran and subsequent Shia political domination in the country. This include Saudi Eastern province, which dominated by Shias who are believed to be under the orbit of Iranian influence; Bahrain which regime has been under the threat of its Shia population and Lebanon which hosts Iran's proxy, Hezbollah, which has been the main challenger to the interest of Saudi Arabia in Lebanon. These are factored in Saudi's close alliance with America and its diplomatic passivity in other parts of the world. In the Horn of Africa, Saudi remained absent to greater extent; nonetheless, on the wake of the outbreak of the Arab Spring and the subsequent Yemen civil war, Saudi Arabia revived its interest in the region as it perceived Iran's presence in the region a threat to its security.

\section{Threat Perception and Saudi Iranian Rivalry in the Horn of Africa}

In this section we borrow from constructivists' notion of threat perception to shed a light on how Saudi Arabia and Iran engaged in competition in the Horn of Africa. Similar perspective will be employed to account for Saudi-Iranian rivalry in the region amid the Arab Spring.

\section{Countering the Iranian Threat: Iran-Saudi Rivalry in the Horn of Africa}

The retreat of Saudi Arabia from the Horn of Africa from 1990s to mid-2000, coincided with the entry of Iran into the region. As noted earlier, Iran's isolation in the Middle East region amid international sanctions pushed her to forge relation with countries like Eritrea in the Horn of Africa as an attempt to maximize its economic and military might vis-à-vis Saudi Arabia (Fakude, 2016b). Iran achieved this momentum in the Horn amid Saudi's preoccupation with balancing the Iranian threat in the Gulf region as Riyadh got closer to the U.S and the West, while it relies on checkbook diplomacy in its engagement with countries of the Horn of Africa. Thus, the expansion of Iran's foreign relations in the region prior to the Arab spring has come to be perceived by Saudi Arabia as a threat. This has become more relevant in the light of escalation of conflicts between Saudi Arabia and Iran in in the Middle East as reflected in their proxy wars in Syria and Yemen. It was the later conflict that prompted Saudi Arabia to increasingly account Iran's expanding relations with countries in the Horn of Africa as a threat to interests.

Saudi's perception of Iran's threat in Horn of Africa is based on the anticipation that Iran will use its penetration in the region and its military agreement with Eritrea to harm Riyadh. This threat perception is not objective and materially-based facts; rather it is socially constructed as ideological division between Iran and 
Saudi Arabia plays a crucial role in creating this social fact. Saudi's perception also drives from its long-term enmity and confrontation with Iran in the Middle East region. Therefore, despite Saudi threat perception of Tehran's capability to harm Riyadh from the Horn of Africa, reality suggests different reality about Iran influence in the Horn of Africa. Whereas Iran has succeeded in building a strong alliance with countries like Eritrea and Sudan in the rein of the ultra-conservative president Ahmadinejad; Iran's influence in the Horn of Africa remained stagnant since the ascendancy of the Iranian current President, Hassan Rouhani, to the presidency of Iran in 2013. Unlike his predecessor's confrontational foreign policy with the West, Rouhani's primary aim was to improve Iran's economic situation as essential to increase Iranian influence in regional and global affairs (Shanahan, 2015). Thus, resolving the nuclear issue has been considered by Rouhani as critical in strengthening Iran's economy and ending its international isolation. Resultantly Hassan Rouhani devoted its foreign policy energy to improving Iran's relations with the West; which ultimately led to The Joint Comprehensive Plan of Action (JCPOA), i.e. international agreement on the nuclear program of Iran, which was reached in Vienna on 14 July 2015 between Iran, the P5+1 and the European Union. (Shanahan, 2015). This and the ongoing war in Syria have consumed Rouhani's foreign policy to continue the legacy of his predecessor in the Horn of Africa. Thus, the Horn of Africa remain on the footnote of Iran's foreign policy priority as there is little diplomatic activities of Iran in the region since Rouhani came to power in 2013.

Despite this, and due to the past experiences with Iran and their rivalry in the Middle East region, Saudi perceived Iran influence in the Horn of Africa as virtual. Accordingly, Saudi's perception that the rise of the Houthis and their consequent alliance with the former president Ali Abdullah Saleh as a typical opportunity for Iran's quest to strengthen relations with political actors in the Yemen deepened Saudi perception that Iran will use the Horn of Africa to supply arms to Houthis. Therefore, Saudi confronted Iran in the Horn of Africa in an effort to subside perceived Iran's influence in a region which is deemed by Saudi Arabia as critical for Iran's attempt to supply arms and military aid to the Houthis in Yemen (Zimmerman, 2016). As such, Saudi Arabia deemed that reviving its foreign policy in the region is unparalleled, especially after Houthi militias have come within the reach of the Straits of Bab Al-Mandab, after capturing Hodaida port and seizing significant materiel from Yemeni government's bases in March 2015.

Although, it easier to claim than to prove Iran's use of the Horn of Africa to supply arms to Houthis in Yemen, Saudi Arabia and its Gulf allies consider this as a row fact as they continued to target Iran's allies in the Horn of Africa to lure them away from Iran (Gumede, 2016). In this context, Saudi's growing activism in the region pushed the countries of the region to make a publicized shift-away from Tehran in 2016. In the case of Sudan, Khartoum started to ditch Iran in favour of Saudi Arabia in 2014 when it closed Iranian cultural centers in Khartoum. This move marked the souring of honeymoon relations between Iran and Sudan, which has been one of Iran's few Arab-Sunni partners. In his 26 years of presidency, Bashir's regime has been smashed with different sanctions for the abuse of rights and for the support for Islamic extremists, including Osama bin Laden. The former has made Bashir wanted on war crimes charges related to the insurgency in the western region of Darfur. This and Khartoum's support of the 1990 Iraqi invasion of Kuwait, spoiled it ties with the countries of the Gulf Cooperation Council, leaving Sudan to turn to Iran, as it remained isolated in the region (Guardian, 2016).

Thus until recently, the Sudanese government has convergent view and position towards regional issues with Tehran than with Riyadh. This has strengthened the relations between two countries as Sudan enjoyed arms deals with Shiite-led Iran for many years. In this context Sudanese intelligence forces were trained by 
Iranians and Tehran helped Khartoum to build its own weapons industry. In return for the Iranian support, Sudan allowed Iran to manufacture weapons on Sudanese soil, which is believed to be used by Iran as a channel to provide arms to Shia and Sunni militant groups in Gaza and Lebanon respectively. The alleged bombing of Sudanese military targets by Israel war planes numerous times in 2009 and 2012 respectively was triggered by the suspect Iran's military activities in the target areas (Sudan Tribune, 2012, 2014). The same allegation was believed to have dictated Saudi Arabia to bar Sudanese President Omar al-Bashir from flying over its territory on his way to Tehran in August 2013 (AllAfrica, 2013). This was followed by Saudi suspension of dealing with Sudanese banks in March 2014, which has seriously affected the movement of cash transaction in Sudan as it also constituted a serious blow to the already fragile economic situation. Although Sudan rejected the report that Saudi decision to suspend dealing with Sudanese banks was politically motivated i.e. to put pressure on Sudan to converge its stand towards regional issues with that of Saudi Arabia, Saudi's freezing dealings with Sudanese banks marked the point of departure for Sudan's self-distancing from Iran and submitting herself to Saudis wishes. Resultantly, Sudan has shuttered Iran's cultural centers in Khartoum and expelled its staffs in September 2014 (Middle East Eye, 2014). Since then Sudan increasingly appears to be assuming greater space in Saudi Arabia's foreign policy.

Unsurprisingly, this has culminated in Sudan firmer commitment to Riyadh and its Gulf allies in March 2015 when it joined the Saudi led- coalition in Yemen against Shia Huthi rebels. This happened at a time when Sudan is already fighting insurgencies in its own country - in the western Darfur region, and South Kordofan and Blue Nile states. In this context, Sudan was believed to have deployed between 350 and 700 ground troops to Yemen in October 2015. Prior to this, Sudan said it had received a $\$ 1$ bn deposit in its central bank from Saudi Arabia, with media reports at the time saying that the amount was aimed at shoring up Sudan's foreign reserves (Taylor, 2016).

Apart from Sudan, Djibouti represents another country in the Horn of Africa that has distanced itself from Iran in favor of Saudi Arabia. Like Sudan, Djibouti enjoyed cordial relations with Iran. In 2009 Iranian then president Ahmadinejad visited East African countries accompanied with higher delegation to expand its trade and investment ties with these countries. In this visit, Iran signed five economic cooperation agreements with Djibouti and granted a credit line to Djibouti. In exchange for this minimal aid and trade agreements, Tehran is alleged to has used Djibouti as a transit port for transporting arms to the Houthis (Taylor, 2016). Given its strategic location as strategic location at the entrance of the Red Sea across from Yemen, where Saudi Arabia and Iran are supporting rival sides in a deadly civil war, Saudi maundered to lure this Sunni predominant country to its orbit in the heyday of the civil war in Yemen. Thus, following the diplomatic row between Riyadh and Tehran in January 2016, Djibouti cut its diplomatic ties with Iran out of solidarity with Saudi Arabia. By aligning with Saudi Arabia, Djibouti was expected to serve as a key position for Riyadh on one of the busiest shipping lanes in the world, and it may get economic deals in return (Taylor, 2016). The Djibouti-UAE diplomatic row in April 2015, which led to diplomatic break off between the UAE and Djibouti and the eviction of UAE and Saudi troops from facility of Haramous, did not preclude Djibouti to stand with Saudi Arabia (Foreign Policy Diary, 2015).

In addition to Sudan and Djibouti, Somalia is yet another country that was trapped in Iran-Saudi rivalry in the Horn of Africa. Bordered by the Gulf of Aden to the north, Somalia is located along one of Iran's primary shipping routes and has received modest aid from Tehran. In recent years, Iran has docked its navy in the Gulf of Aden off the coast of Somalia to curtail piracy and protect Iranian shipping. In recent years, Iran has been 
trying to gain a stronger foothold in Somalia; nonetheless, political experts said relations between the two countries have remained minimal and not without conflict. For example, Mogadishu has repeatedly accused Tehran of supporting Islamic insurgent groups in Somalia. Despite this, the Somali national government has enjoyed modest aid from Iran (Winsor, 2016). Somalis, who are almost entirely Sunni Muslims, also had a long-standing relationship with Saudi Arabia, the home of Islam's holiest site and thousands of Somali refugees and students. There ties have grown as Somalia tries to rebuild a nation while fighting an Islamist insurgency. In return for this, Somalia supported Saudi's military involvement in Yemen. In April 7th 2015, Somalia Foreign Minister Abdisalam Hadliye said that his country gave a green light for its airspace, territorial waters and land to be used for Saudi-led air strikes against the Houthi rebels in Yemen (Guardian, 2016). This was followed by the visit of Somalia's president, Hassan Sheikh Mohamud, to Riyadh to meet King Salman bin Abdul Aziz al-Saud in Saudi Arabia in October 2015. In the context of this, a Saudi team visited Somalia to discuss further Saudi support for the country. In light of this and the Saudi continued humanitarian works in Somalia, Mogadishu appeared defenseless before Saudi's plead to Sunni countries to rally behind Riyadh. Accordingly, as Saudi's efforts to shore up regional support against Iran escalated following the execution of a Shi'ite cleric and Iranian protesters responded by torching the Saudi embassy in Tehran, Somali, with no vacillation, cut relations with Iran in January 2016 on the ground that Tehran had meddled in Saudi's affairs and threatened its national security. Mogadishu gave Iranian diplomats 72 hours to leave the country. Following this move, Somalia received a pledge of aid for \$50 million from Saudi Arabia (Reuters, 2016).

Likewise, Eritrea, which has been a strong ally of Iran in the region, has turned towards Saudi Arabia and its Gulf allies amid their collective military action in Yemen. Eritrea, located along one of the world's occupied shipping lanes on the Red Sea, is less than 100 kilometers (62 miles) across the watercourse from Yemen at its closest point. It was sanctioned by the UN in 2009 after the government was accused of sending 2,000 troops to Somalia to reinforce an insurgency by al-Qaeda-linked militants (Gridneff, 2015). In the Horn of Africa, Eritrea is one of the countries that supported Iran's right for nuclear program. Its president have reiterated this in several occasions. In his speech to Non-Aligned Movement in November 2007, Eritrean President Isais Afwerki said that nuclear energy is Iran's legal right and that Iran has right to enrich uranium for peaceful purposes. As Eritrea relations with the West strained following its war with Ethiopian 2008-2000, which triggered Western sanctions against Asmara, Iran became Eritrea's new-found partner as two countries expanded their economic and political and diplomatic cooperation (Gridneff, 2015). In 2008, Eritrea signed trade and investment agreements with Iran as the latter showed its willingness to support energy and infrastructure development projects in Eritrea. Additionally, Iran and Eritrea have agreed to increase their bilateral political relations in May 2008, when President Afwerki met with Iranian President Ahmadinejad in Tehran. In this context, Eritrea hosted the Iranian military base and approved her to have an access to its territorial water and it port of Assab. This has aroused the apprehension of many countries including Israel and Arab countries who alleged that Iran's exploited its ties with Eritrea to smuggle weapons to Houthis in Yemen and Hamas and Palestine. Such allegations were denied by Eritrean President Afwerki who described Iranian-Eritrean relations "are relatively new" but "constructive" while he denied that Eritrea is hosting Iranian military bases to allow Tehran smuggle arms to Palestinians (Farrar-Wellman, 2010).

In the backdrop of this, it has been a surprising development that Eritrea forged allies with Saudi Arabia and other Gulf countries in their military engagement in Yemen. However, this could be understood if we put into the account the juxtaposition of the consumption of Iran's foreign policy by the nuclear talk with 5+1 and 
its devoted engagement in Syria and Iran on the one hand, and the Eritrea's efforts to break its isolation in the region and its need for cash and resources, which appeared to be met by the Gulf countries. Saudi's supposition that Iran is using Eritrea to extend military aid to Houthis is another primary factor that facilitated the recent Saudi-Eritrean rapprochement. This rapprochement with Saudi Arabia has pushed Eritrea to offer its port of Assab to be used as an air-sea logistical hub for Saudi-Emirati operations. This came after Saudi and UAE troops were evicted from their base in Djibouti following the diplomatic row between the UAE and Djibouti (Mello \& Knights, 2016). Given the strategic importance of the Horn of Africa to Saudi's, Djibouti's eviction of Gulf troops dictated Saudi Arabia and UAE to alternate Djibouti with Eritrea. Consequently, Eritrea concluded a security and military partnership agreement with the Gulf States offering basing rights in Eritrea. This agreement was reached during the visit of President Isaias Afewerki to Riyadh to meet with Saudi Arabia's King Salman bin Abdel Aziz (Mello \& Knights, 2016). This was followed by a high-level delegation from the Gulf Cooperation and Council to meet Eritrean officials in Asmara to discuss using Eritrea as potential base for operations. Within the framework of this military agreement between the GCC countries and Eritrea, the United Arab Emirates concluded a 30-year lease agreement to use the mothballed deep-water port at Assab and the nearby hard-surface Assab airfield as military base. The Gulf States reciprocated this offer by Eritrea with an agreement to provide a financial aid package to Eritrea, to modernize Asmara International Airport, build new infrastructure, and increase fuel supplies to Eritrea (Foreign Policy Diary, 2015).

As mentioned earlier, the surge in Saudi diplomatic and political engagements with countries of the Horn of the Africa is ignited by the perceived threats of Iran, which is believed to emanate from the region. This threat is bolstered by the historical confrontation between Riyadh and Tehran, which shaped by regional rivalry over position and influence in the Middle East region. The escalation of Yemen war is sufficient for Saudi Arabia to seek patronage for the countries of the Horn of Africa which ditched Iran in favor of Saudi Arabia. Seemingly, Saudi has reaped the gain for its engagement in the Horn of Africa which show their commitment to support Saudi Arabia, as manifested in break off their relations with Iran and installation of Gulf military bases on their soils as well as their pronounced support for the Saudi led Arab coalition military operation in Yemen, and their membership in Saudi led Muslim coalition for combating terrorism (Winsor, 2016).

\section{Conclusions}

The Saudi Iranian rivalry in the Horn of Africa is triggered by juxtaposition of Iran's efforts to balance the power of Saudi Arabia in the Middle East and Saudi's diplomatic endeavor to subside the perceived threats of Iran in the Horn of Africa. The escalation of their rivalry in the Horn of Africa is particularly directed and shaped by dynamic of Middle East regional politics; yet the strategic location of the Horn of Africa and its importance to the regional ambitions of both countries has made the region intrinsically attractive. The shaped foreign polices of Saudi Arabia and Iran towards Sudan, Eritrea, Djibouti and Somalia for the past two decades. While Saudi's revival of its foreign policy in the Horn of Africa outdid Iran's influence since the outbreak of the civil war in Yemen, it is yet to be known whether Saudi will maintain its ties with these countries in a long-term. In light the dynamic of changes in the political, economic and security contexts of the Middle East region, which apparently made Iran stronger visa-via Saudi Arabia, the Kingdom's bid to balance the perceived threats of Iran in the Horn of Africa is hardly sustainable. This is even more acute when we consider the global collapse in oil prices and economic pressures on Saudi Arabia, which might force Riyadh to scale back the use of checkbook diplomacy in its foreign policy towards the Horn of Africa, and the conclusion of the 
international agreement on Iran's nuclear programme between the P5+1 and Iran, which will permit Tehran to become more assertive in the regional arena and to push its influence to challenge Saudi Arabia's sphere including.

\section{References}

Aarts, P., \& Pwhaartsuvanl, E. (n.d.). Saudi Arabia and the Arab uprisings: National, regional, and global responses. Workshop of Gulf Research Meeting, 2-5 July 2013, University of Cambridge, United Kingdom.

Abdollahian, H. A., \& Ahmadinejad, F. (2013). Iran's awkward diplomacy in Africa. Retrieved from http://nationalinterest.org/feature/irans-awkward-diplomacy-africa-15571

Adler, E. (2008). Constructivism and international relations. Handbook of International Relations, 95-118. Retrieved from http://doi.org/10.4324/9780203401880

Akinsanya, A. A. (2010). Afro-Arab Relations and North Africa.

AllAfrica. (2013). Sudan's Al-Bashir denied Saudi Air space. Retrieved September 15, 2016, from http://allafrica.com/view/group/main/main/id/00025870.html

Baldwin, D. A. (1993). Neoliberalism, Neo-Realism, and world politics: Neo-Realism and neoliberalism: The Contemporary Debate, 3-25. Retrieved from http://doi.org/10.1016/S0969-4765(04)00066-9

Crockatt, R., Sayigh, Y., \& Bromley, S. (1997). The cold war: Global conflict, regional upheavals. In F. Halliday (Ed.), The Middle East in international relations: Power, politics and ideology (pp. 97-129). Publisher: Cambridge University Press

Cronin, S., \& Masalha, N. (2011). The Islamic Republic of Iran and the GCC states: Revolution to realpolitik? London School of Economic and Political Science Kuwait Programme on Development, Governance and Globalization in the Gulf States, (17). Retrieved from http://www.lse.ac.uk/government/research/resgroups/kuwait/documents/Cronin and Masalha.pdf

Donnelly, J. (2000). Realism and international relations. Cambridge: Cambridge University Press.

Downs, K. (2012). A theoretical analysis of the Saudi-Iranian rivalry in Bahrain. Journal of Politics and International Studies, 8, 203-237.

Retrieved

from http://www.polis.leeds.ac.uk/assets/files/students/student-journal/ug-winter-12/130213-win12-kevin-downs-6.pdf

Dreyer, D. R. (2012). Issue intractability and the persistence of international rivalry. Conflict Management and Peace Science, 29(5), 471-489. Retrieved from http://doi.org/10.1177/0738894212449090

Dreyer, D. R. (2014). Unifying conceptualizations of interstate rivalry: A min-max approach. Cooperation and Conflict, 49(4), 501-518. Retrieved from http://doi.org/10.1177/0010836713519980

Fakude, T. (2016a). South Africa: Between Iran and Saudi Arabia? Retrieved from http://www.aljazeera.com/indepth/opinion/2016/03/south-africa-iran-saudi-arabia-160331113354567.html

Fakude, T. (2016b). The impact of the South Africa-Iran relations on the African Union. Retrieved from http://studies.aljazeera.net/en/reports/2016/02/impact-south-africa-iran-relations-african-union-160228101501661.html

Farrar-Wellman. A. (2010). Eritrea-Iran foreign relations. Iran Traker. Retrieved September 15, 2016, from $\mathrm{http} / / / \mathrm{www}$.irantracker.org/foreign-relations/eritrea-iran-foreign-relations

Foreign Policy Diary. (2015). Arab coalition expands into the Horn of Africa. Retrieved October 17, 2016, from http://www.liveleak.com/view?i=36a_1446820766\#3k38s8SbpxAD0BVv.99

Gridneff, I. (2015). Saudi Arabia, U.A.E paying Eritrea to back Yemen fight, UN says. Retrieved October 23, 2016, from http://www.bloomberg.com/news/articles/2015-11-05/saudi-arabia-u-a-e-paying-eritrea-to-back-yemen-fight-un-says

Guardian. (2016). Why has Sudan ditched Iran in favor of Saudi Arabia? Retrieved September 9, 2016, from https://www.theguardian.com/world/2016/jan/12/sudan-siding-with-saudi-arabia-long-term-ally-iran

Gumede, W. (2016). Saudi Arabia reaches out to Africa. African Independence. Retrieved July 4, 2016, from http://www.africanindy.com/outlook/saudi-arabia-reaches-out-to-africa-1575212

Guzansky, Y. (2015). The Arab Gulf States and reform in the Middle East: between Iran and the "Arab Spring”, 9770 (April), 147. Retrieved from http://doi.org/10.1057/9781137467836

Hellmann, G., \& Wolf, R. (1993). Neo-Realism, neoliberal institutionalism, and the future of NATO. Security Studies, 3(1), 3-43. Retrieved from http://doi.org/10.1080/09636419309347537

Hopf, T. (1998). The promise of constructivism in international relations theory. International Security, 23(1), 171-200. Retrieved from http://doi.org/10.2307/2539267

Hunter, S. (2010). Iran's foreign policy in the Post-Soviet era: Resisting the new international order. Retrieved from 
http://doi.org/10.1007/s13398-014-0173-7.2

Jordaan, E. (2008). Barking at the big dogs: South Africa's foreign policy towards the Middle East. Round Table, 97(397), 547-559. Retrieved from http://doi.org/10.1080/00358530802207344

Keohane, R. O. (1986). Theory of world politics: Structural Realism and beyond. In R. O. Keohane (Ed.), Ne-Realism and its critics (pp. 332-346). New York: Columbia University Press.

Lefebvre, J. A. (2012). Iran in the Horn of Africa: Outflanking US allies. Middle East Policy, 19(2). DOI: 10.1111/j.1475-4967.2012.00539.x

Long, D. A. (1990). Saudi Arabia and the Horn of Africa, in D. A. Korn \& S. R. Dorr (Eds.), The Horn of Africa and Arabia. Florida USA: Defense Academic Program Research.

Matthiesen, T. (2015). The domestic sources of Saudi foreign policy: Islamists and the state in the wake of the Arab uprisings. Washington, D.C.: Brookings Institution.

Mello, A. \& Knights, M. (2016). How Eretria became major UAE military base. TesfaNew. Retrieved October 19, 2016, from https://www.tesfanews.net/west-of-suez-for-the-united-arab-emirates/

Middle East Eye. (2014). Iran, Saudi Arabia jostle for influence in Sudan as Iranian cultural centre shut down. Retrieved October 15, 2016, from http://www.middleeasteye.net/news/iran-saudi-arabia-jostle-influence-sudan-iranian-cultural-centre-shut-down-61716582

Mitchell, S., \& Thies, C. (2011). Issue rivalries. Conflict Management and Peace Science, 28(3), 230-260. Retrieved from http://doi.org/10.1177/0738894211404794

Moravcsik, A. (1997). Taking preferences seriously: A liberal theory of international politics. International Organization, 51(4), 513-553. Retrieved from http://www.princeton.edu/ amoravcs/library/preferences.pdf

Morgenthau, H. J. (1965). Review: Scientific man vs. power politics. American Sociological Review, 12(2), $236-237$. http://doi.org/10.2307/2086992

Obala, L. M. (2011). Africa and the Arab World after Gaddafi. Al Jazeera Centre for Studies.

Reuters. (2016). Somalia received Saudi aid the day it cut ties with Iran: Document. Retrieved September 15, 2016, from http://www.reuters.com/article/us-somalia-saudi-iran-idUSKCNOUV0BH

Rizwan, M., Iram, S., \& Waqar, M. (2014). From rivalry to nowhere: A story of Iran-Saudi ties. IOSR Journal of Humanities and $\begin{array}{lllll}\text { Social Science } & \text { (IOSR-JHSS), } & \text { 19(9), } & \text { 91-101. } & \text { Retrieved }\end{array}$ http://www.iosrjournals.org/iosr-jhss/papers/Vol19-issue9/Version-4/P0199491101.pdf

Rohde, C., \& Morgenthau, H. J. (n.d.). Under Weltpolitische Realism us. Wiesbaden: VS Verlag für Sozialwissenschaften .

Salisbury, P. (2015). Yemen and the Saudi-Iranian "Cold War". Retrieved from https://www.chathamhouse.org/publication/yemen-and-saudi-iranian-cold-war

Shanahan, R. (2015). Iranian foreign policy under Rouhani. Lowy Institute.

Sudan Tribune. (2012). Sudan accuses Israel of bombing military factory, talks of “inside job”. Retrieved September 29, 2016, from http://www.sudantribune.com/spip.php?article44324

Sudan Tribune. (2014). Sudan says Saudi decision to suspend banking transactions not politically motivated. Retrieved September 15, 2016, from http://sudantribune.com/spip.php?article50164

Taylor, M. (2016). Horn of Africa States follow Gulf into the Yemen War. The Africa Report. Retrieved from http://www.theafricareport.com/East-Horn-Africa/horn-of-africa-states-follow-gulf-into-the-yemen-war.html

Walt, S. M. (1998). International relations: One world , many theories. Foreign Policy, 110, 29-32.

Waltz, K. N. (1988). The origins of war in neorealist theory. Journal of Interdisciplinary History, 18(4), 615-628. Retrieved from http://doi.org/10.2307/204817

Wehrey, F. (2011). Uprisings jolt the Saudi-Iranian rivalry. Current History, 110(740), 352-357.

Wehrey, F., Karasik, T., Nader, a, Ghez, J., \& Hansell, L. (2009). Saudi-Iranian Relations since the fall of Saddam: Rivalry, cooperation, and implications for $\quad$ US policy. Retrieved from http://books.google.com/books?hl=en\&lr=\&id=g6jobzFgpLYC\&oi=fnd\&pg=PP1\&dq=Saudi-Iranian+Relations+Since+the+ Fall+of+Saddam:+Rivalry,+Cooperation,+and+Implications+for+U.S.+Policy\&ots=WJiIQzPnON\&sig=ATF_u014opYm7y 1QOrHz7UfX1R0

Wendt, A. (1992). Anarchy is what states make of it: The social construction of power politics. International Organization, 46(2), 391-425. Retrieved from http://doi.org/10.1017/S0020818300027764

Wendt, A. E. (2014). The agent-structure problem in international relations theory. Retrieved from http://doi.org/10.1017/S002081830002751X 
Winsor, M. (2016). Saudi Arabia-Iran rivalry in Africa: Sudan, Djibouti, Somalia part ways with Tehran as Riyadh influence grows. International Business Times. Retrieved October 15, 2016, from http://www.ibtimes.com/saudi-arabia-iran-rivalry-africa-sudan-djibouti-somalia-part-ways-tehran-riyadh-2255456

Yaphe, J. S. (2008). Challenges to Persian Gulf security: How should the United States respond? Strategic Forum, $237,1-8$.

Yoh, J. G. (2001). Reflections on Afro-Arab relations an African perspective. Paper presented to the Monthly Seminar Arab Thought Forum, Amman, 16 October.

Zimmerman, K. (2016). Signaling Saudi Arabia: Iranian Support to Yemen's al Houthis. Critical Threat. Retrieved from: https://www.criticalthreats.org/analysis/signaling-saudi-arabia-iranian-support-to-yemens-al-houthis

Zoppi, M. (2013). Exploiting the religious link: Saudi Agenda in Africa and its effects in Somalia and Mali. http://www.amec.org.za/images/2013Conference/Marco\%20Zoppi\%20AMEC\%20final\%20paper-1.pdf 